\title{
The Yin Yang of Hormones that Control Glucose Homeostasis in Asthma
}

\author{
Daniella BR Insuela, Patrícia MR Silva, Marco A Martins and Vinicius F Carvalho*
}

Laboratório de Inflamação, Instituto Oswaldo Cruz, Fundação Oswaldo Cruz, Brazil

\begin{abstract}
Asthma is a chronic inflammatory disease whose prevalence has increased in the last 50 years. Several hormones can determine the course of asthma pathogenesis. Furthermore, some endocrine disorders, including diabetes and obesity, have been identified as important factors that influence the prevalence of asthma. These endocrine disorders are characterized by presenting an imbalance in blood hormones levels that regulate glucose metabolism, including hyperglycemic and hypoglycemic hormones. This review gives an update of the state-of-the-art concerning the effect of hormones that control glucose homeostasis on asthma pathogenesis and development. Here, we proposed that while hypoglycemic hormones, including insulin and leptin aggravate asthma, the hyperglycemic hormones, as glucagon, glucocorticoids and epinephrine, have a protective effect on asthma.
\end{abstract}

Keywords: Asthma; Glucagon; Glucocorticoid; Glucose metabolism; Hormones; Insulin

\section{Introduction}

Asthma is one of the main chronic diseases of contemporary man, affecting people in countries at all stages of economic and social development and is a major public health burden worldwide. The global prevalence of asthma has markedly increased over the last 50 years. Around 300 million people have asthma worldwide, and each year 250 thousand people die due to this disease [1,2]. Asthma is a chronic inflammatory disease of the lungs characterized by variable airway obstruction in association with airway hyperresponsiveness (AHR) that leads to symptoms including recurrent episodes of wheezing, chest tightness and coughing $[3,4]$.

The inflammatory response observed in airways of asthmatic patients is characterized by accumulation of mast cells, eosinophils and type $2 \mathrm{CD}^{+} \mathrm{T}$ cells (Th2 cells). Th2 cells are central to the pathogenesis of asthma, since Th2-type cytokines orchestrate the allergic inflammatory response in asthma, including $\operatorname{IgE}$ synthesis, Th2 cells, eosinophils and mast cells survival, eosinophil and mast cell maturation and basophil recruitment [3,5]. Moreover, the infiltration of type $17 \mathrm{CD}^{+} \mathrm{T}$ cells (Th17 cells) in the airway walls of some asthmatic patients and the severity of AHR is correlated with the presence of these cells. This evidence suggests the role of Th17 cells in driving airway inflammation and pathological changes in some cases of asthma. In fact, activation of Th17 cells is closely associated with asthma severity, neutrophil recruitment and development of steroid-resistance in asthmatic subjects [6,7]. Moreover, asthmatics show structural changes in the airway wall called airway remodeling. These changes including epithelial shedding increased airway smooth muscle mass and mucusproducing goblet cells in the epithelium or submucosal glands and subepithelial fibrosis [4].

In type 1 diabetes, glucagon and insulin secretion from pancreatic $\alpha$ - and $\beta$-cells, respectively, become dysregulated with hypersecretion of glucagon and hyposecretion of insulin resulting in hyperglycemia [8]. Uncontrolled type 1 diabetic patients present a lower prevalence of allergic diseases, including asthma $[9,10]$. One hypothesis to explain this negative correlation between type 1 diabetes and asthma is that autoimmune diseases, including diabetes, involve a Th1 response while allergic diseases are associated with the Th2 phenotype [11,12]. We showed that alloxan-diabetic rats presented decrease in the allergeninduced acute protein leakage and eosinophil infiltration in skin, intestine and pleural space. This suppression of allergic responses in diabetic rats was correlated with reduction in IgE synthesis and number of local mast cells [13-16].

\section{Hypoglycemic Hormones and Asthma}

The maintenance of glucose homeostasis requires a tight regulation of glucose utilization by liver, muscle and fat, besides the glucose production and release in the blood by liver. This homeostatic process is controlled by two classes of hormones: i) hypoglycemics that induce uptake of glucose to peripheral tissues; ii) hyperglycemics that stimulate hepatic glycogenolysis and gluconeogenesis [17]. Among the hypoglycemic hormones, stands insulin that is produced by pancreatic $\beta$ cells and acts by inhibiting hepatic gluconeogenesis and glycogenolysys and stimulating glucose storage by liver, muscle and fat as promoting glucose uptake and utilization by muscle and adipose tissues [18].

In diabetic patients, treatment with inhaled insulin induces decrease in forced expiratory volume in 1 second (FEV-1) [19]. Moreover, uncontrolled insulin-dependent diabetic patients present a less incidence of asthma $[9,10]$. In inflammatory and structural cells involved in asthma pathogenesis, insulin is able to modulate $\mathrm{T}$ cell differentiation promoting a shift towards a Th2-type response, which is central to the pathogenesis of asthma, with an increase in the number of Th2 cells and Th2-cytokine profile [20]. Furthermore, insulin promotes mast cell survival and a more robust antigen-triggered mast cell degranulation $[21,22]$, and enhances contractility and proliferation of airway smooth muscle [23], through a mechanism dependent on PI3K pathway activation $[21,24]$. In keeping with this, hyporesponsiveness to antigen observed in the airways and pleural space of diabetic rats was reversed by treatment of the animals with insulin [25,26]. In association, these evidences indicate that insulin seems to aggravate asthma symptoms.

*Corresponding author: Vinicius F Carvalho, Laboratório de Inflamação, Fundação Oswaldo Cruz, Av. Brasil, n 4365, Manguinhos, Rio de Janeiro, Brazil, Tel: 55-21-2562-1334; Fax: 55-21-2562-1357; E-mail: vfrias@ioc.fiocruz.br

Received December 15, 2012; Accepted January 10, 2013; Published January 15,2013

Citation: Insuela DBR, Silva PMR, Martins MA, Carvalho VF (2013) The Yin Yang of Hormones that Control Glucose Homeostasis in Asthma. J Aller Ther S11: 001. doi:10.4172/2155-6121.S11-001

Copyright: (c) 2013 Insuela DBR, et al. This is an open-access article distributed under the terms of the Creative Commons Attribution License, which permits unrestricted use, distribution, and reproduction in any medium, provided the original author and source are credited. 
Although insulin is the major hypoglycemic hormone, it is known that other hormones can reduce the circulating levels of glucose. These hormones are produced by adipose tissue, including adiponectin and leptin, and gastrointestinal tract, as glucose-dependent insulinotropic peptide (GIP) and glucagon-like peptide-1 (GLP-1) [27,28]. Animal models of untreated type 1 and type 2 diabetes present leptin deficiency accompanied by insulin resistance [29,30], and central or peripheral leptin administration was able to restore normoglycemia in animal models of type 1 and type 2 diabetes [31-35]. This hypoglycemic effect of leptin in diabetes is associated with lowers circulating glucagon levels, decreases gluconeogenic gene expression and improves insulin sensitivity and release [35]. Furthermore, leptin is able to suppress glucose production in non-diabetic animals by a mechanism associated with decrease of hepatic glycogenolysis without affecting glucose uptake [36].

Receptors for both leptin and adiponectin are expressed in lungs [37], however only some experimental evidences supported that leptin and adiponectin could have a role in the pathogenesis of asthma. Leptin has a pro-inflammatory profile in cells that have an important role in asthma, including mast cell activation, $\mathrm{CD} 4^{+} \mathrm{T}$ cells proliferation and induction of cytokine release and migration of eosinophils [38-41]. Furthermore, leptin increases inflammatory cells mobilization to bronchoalveolar fluid and airway hyperreactivity following allergen challenge [42].

In addition to leptin, another important hormone produced by adipose tissue that influences glucose homeostasis is adiponectin. Adiponectin induces decrease of systemic glucose levels by increasing glucose uptake, reducing hepatic glucose production and improving insulin sensitivity [43-45]. Unlike leptin, adiponectin seems to present an anti-asthmatic profile since adiponectin knockout mice presented an increase of allergic airway inflammation [46], and adiponectin administration was able to reduce allergen-induced airway hyperreactivity and inflammation in mice [47]. However, adiponectin may have an important pro-inflammatory action in severe asthma and, especially, in steroid-resistance in asthmatic subjects since this hormone is highly expressed in synovium of patients with rheumatoid arthritis $[48,49]$, activates synovial fibroblast inducing cytokine release and matrix degrading effects [50,51], and induces maturation and activation of dendritic cells polarizing naïve CD4+ T cells into Th17 phenotype [52].

GIP and GLP-1 modulate glucose homeostasis through of an "incretin" effect, which is a potentiation of glucose stimulated insulin secretion in an additive manner [53,54]. However, until now there is no information about the role of these incretins on allergic diseases, including asthma, and on inflammatory cells which are central in development of asthma.

\section{Hyperglycemic Hormones and Asthma}

The hyperglycemic hormones are secreted during fasting to maintaining blood glucose levels and preventing hypoglycaemia. Glucagon is secreted by pancreatic $\alpha$-cells, and considered as the body's primary defence against low blood glucose levels [55]. Glucagon induces hyperglycemia through stimulation of synthesis and mobilization of hepatic glucose, by activating glycogenolysis and gluconeogenesis and inhibition of glycolysis and glycogenesis [56,57]. Here, we showed that mice treated i.p. with glucagon for 7 consecutive days presented a reduction in the plasma insulin levels (Figure 1), which could be partly explained by the hyperglycemic effect of this hormone too. Moreover, although fasting plasma glucagon levels are not elevated in patients
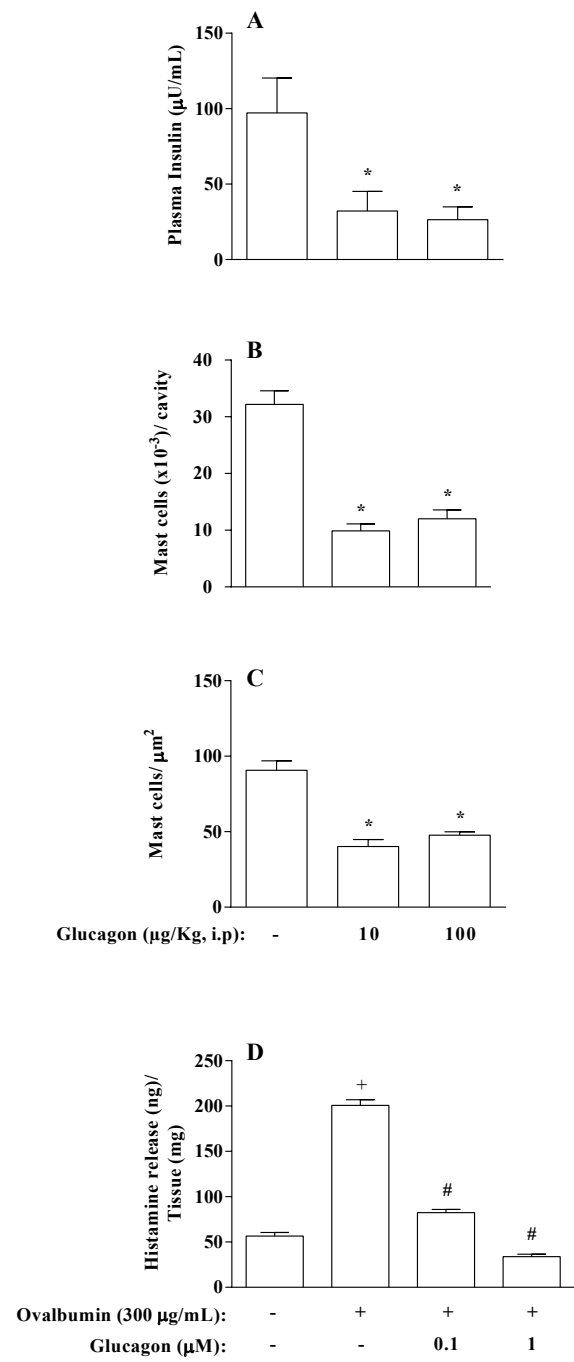

Figure 1: Glucagon reduces plasma insulin levels, peritoneal and mesenteric mast cell numbers, and mast cell reactivity in vitro.

Glucagon (10 or $100 \mu \mathrm{g} / \mathrm{Kg}$, i.p.) was administered once a day for 7 days in male Swiss-Webster mice. Then, plasma insulin levels, peritoneal and mesenteric mast cell numbers were evaluated (A, B and C, respectively). Data are expressed as mean \pm S.E.M. of 6 animals. ${ }^{*} P<0.05$ as compared to untreated mice. (D) Hypodermic tissue was removed from actively sensitized rats and challenged with OVA $(300 \mu \mathrm{g} / \mathrm{ml})$ in vitro during $1 \mathrm{~h}$, and supernatan was recovered to histamine evaluation by fluorescence. Treatment with glucagon $(0.1$ or $1 \mu \mathrm{M})$ was realized in vitro $1 \mathrm{~h}$ before challenge. Data are expressed as mean \pm S.E.M. of 4 replicates. $+P<0.05$ as compared to nonchallenged tissue; $\# \mathrm{P}<0.05$ as compared to ovalbumin-challenged tissue.

with type 1 and type 2 diabetes [58,59], significant elevations were shown with serial sampling in both type of diabetes $[60,61]$.

In asthmatic patients, glucagon presents a relaxant action on the airway smooth muscle inducing an improvement in the lung function $[62,63]$, however this effect of glucagon needs to be further elucidated since some studies did not show any significant bronchodilator effect of glucagon on these patients $[64,65]$. Despite this controversy about the bronchodilator effect of glucagon in asthmatics, the lungs of rats express glucagon receptor $(\mathrm{GcgR})$, and glucagon relaxes guinea pig bronchiolar smooth muscle in vitro independently of $\beta$-adrenergic receptor stimulation $[66,67]$. We showed that glucagon inhibited the allergenevoked histamine release from rat subcutaneous tissue fragments in vitro (Figure 1), indicating a putative mast cell-stabilizing properties by 
this hormone. Moreover, i.p. daily treatment with glucagon for 7 days induced a decrease in peritoneal and mesenteric mast cell numbers in a clear association with reduction of plasma insulin levels (Figure 1). Other important inflammatory cells for development of asthma that may have its activity negatively modulated by glucagon are lymphocytes, since these cells express GcgR. However, although lymphocytes express GcgR, this hormone was not able to change the proliferation of these cells induced by anti-CD3 or LPS [68]. Nevertheless, glucagon can act reducing Th2 cytokine production by lymphocytes since the activation of GcgR induces an increase in the intracellular cAMP levels [67], and forskolin, an adenylate cyclase activator that elevates cAMP, induces apoptosis of T cells in vitro [69].

Beyond glucagon, others hormones including epinephrine and glucocorticoids increasing blood glucose levels in response to hypoglycemia and stress situation [17]. Epinephrine is mainly produced in the adrenal medulla by a methylation reaction from norepinephrine catalyzed by the enzyme phenylethanolamine $\mathrm{N}$-methyltransferase. Epinephrine induces hyperglycemia through activation of glycogenolysis and hepatic gluconeogenisis, stimulation of glucagon and inhibition of insulin release, and induction of insulin resistance. As glucagon, epinephrine induces glycogenolysis and gluconeogenisis by increasing the intracellular levels of cAMP through the activation of $\beta$-adrenergic receptors [70,71]. Although, epinephrine is less potent in inducing hyperglycemia than glucagon, epinephrine becomes essential in the control of glucose homeostasis when glucagon actions are impaired, [72].

Airway smooth muscle expresses all subtypes of epinephrine receptors, with predominance of the $\beta_{2}$ receptors. The activation of these receptors in airway smooth muscle promotes opposite effects; while a receptors induces contraction, the $\beta$ receptors relax the muscle. An imbalance in the expression of these receptors on airway smooth muscle could be involved in the etiology of bronchial asthma [73]. Moreover, it was observed that asthmatic patients present a decrease in levels of endogenous epinephrine and this fact could explain the high effectiveness associated to the administration of exogenous epinephrine on asthma [74]. Furthermore, epinephrine was used as a standard treatment for severe asthma before the development of $\beta_{2}$ receptors selective agonists. Nowadays, epinephrine is used when asthmatic patients do not respond to the conventional treatment $[75,76]$ and the inhaled $\beta_{2}$ agonists associated with inhaled corticosteroids became the standard therapy for asthma [77]. In addition, activation of $\beta_{2}$ receptors inhibits the function of various inflammatory cells involved in asthma pathogenesis, including IgE-evoked release of histamine, PGD2 e cysteynil-leukotrienes by mast cells [78]; ovalbumin-induced airway eosinophil infiltration and adhesion of eosinophils to lung fibroblast $[79,80]$; IL-4 and IL-13 production by human T cells $[81,82]$; proinflammatory and pro-fibrotic mediators release and matrix production by lung fibroblasts $[83,84]$.

Glucocorticoids are produced in the adrenal cortex under the control of hypothalamic-pituitary-adrenal (HPA) axis [85]. Moreover,

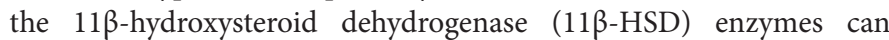
modulate the biological effects of glucocorticoids in target tissues since $11 \beta$-HSD type 1 amplifies local glucocorticoids action by conversion of cortisone to cortisol [86]. Glucocorticoids increase blood glucose by increasing hepatic glucose production, decreasing insulin-dependent glucose uptake into peripheral tissues, and inhibiting insulin release from pancreatic $\beta$-cells [87]. Furthermore, disruption of glucocorticoid receptor (GR) in hepatocytes leads to hypoglycemia during prolonged starvation, and inactivation of GR in hepatocytes reduces blood glucose levels in streptozotocin-induced diabetes [88].

Currently, glucocorticoids are recommended as first-line therapy for all patients with persistent asthma [89]. Glucocorticoids have its anti-inflammatory effect on several structural and inflammatory cells involved in asthma pathogenesis [90]. In inflammatory cells, glucocorticoids inhibit activation and proliferation of $\mathrm{T}$ cells and induce apoptosis of $\mathrm{T}$ cells, B cells, eosinophils and mast cells [91]. Moreover, glucocorticoids suppress the activity of the transcription factor GATA-3, that regulates the expression of genes encoding cytokines involved in asthma pathophysiology including IL-4, IL-5 and IL-13, in Th2 cells which results in decreased production of these cytokines by these cells [92]. However, the action of glucocorticoids in Th17 cells is not well established yet. Although glucocorticoids are able to reduce the production of IL-17 in asthmatics [93], this hormone does not inhibit cytokine production by Th17 cells in vitro, and the treatment with dexamethasone in vivo did not minimize inflammation and hyperreactivity of the airways of mice that received Th17 cells and were challenged with ovalbumin [94]. Furthermore, glucocorticoids inhibit the release of Th2-cytokines, including IL-4 and IL-5, and lipid mediators by eosinophils and mast cells [91]. We previously described that alloxan-induced diabetic rats presented an increase in the circulating corticosterone levels [14,95]. Besides, the decrease in the mast cell numbers and reactivity and antigen-induced IgE production as well as reduction of local and systemic antigenic response noted in alloxan-induced diabetes were reversed by surgical removal of adrenal glands and by treatment with the glucocorticoid receptor blocker RU486 [13,96].

In structural cells, glucocorticoids inhibit airway smooth muscle proliferation in vitro [97]. It also has been demonstrated that treatment with budesonide, an inhaled glucocorticosteroid, prevents airway smooth muscle thickening, contractile protein expression and tracheal hypercontractility in guinea pigs sensitized and challenged with ovalbumin [98]. Glucocorticoids are also able to inhibit airway smooth muscle contraction promoted by histamine, bradykinin or acetylcholine in vitro in a mechanism that involves increase in the intracellular levels of cAMP in airway smooth muscle cells [99]. Moreover, it was demonstrated that glucocorticoids increase the expression of $\beta_{2}$ receptor in human lungs in vitro and in nasal mucosa in vivo, which could prevent the down-regulation of these receptors after prolonged administration with $\beta_{2}$ agonists and thus enhance the effects of these agonists [77]. Besides, glucocorticoids inhibit cytokine generation by airway smooth muscle cells and epithelial cells $[100,101]$; however it is not defined if this hormone has a damaging or protective effect on epithelial cells, because some studies demonstrated that glucocorticoids increase apoptosis and epithelial shedding while others observed that the therapy with inhaled glucocorticoids restored epithelium integrity [101]. The anti-asthmatic action of glucocorticoids on pulmonary fibroblasts remains undefined. This is because, although glucocorticoids inhibit the production of fibronectin by stimulated lung fibroblast, it partially reduced the airway wall thickening and matrix deposition in a rat model of airway remodeling induced by allergen [102], decreased proliferation and liberation of inflammatory mediators by pulmonary fibroblasts, and reduced basement membrane thickness in airway biopsies from asthmatic patients [103], this hormone presents an anti-apoptotic effect on fibroblasts [103] and does not alter the ECM deposition in the reticular basement membrane in the airways [104].

Finally, an adrenal suppression has been reported in untreated allergic and asthmatic patients [104]. This phenomenon could be associated with the modulation of HPA axis activity by inflammatory 
response noted in these patients, since corticotropin-releasing factor (CRF) knockout mice showed a decrease in endogenous glucocorticoid production in close-relationship with increase in airway inflammation with mechanical dysfunction of the lungs and increased levels of IL4, IL-5 and IL-13 [105]. Together, these evidences demonstrated that patients with severe asthma exhibit a relative adrenal insufficiency that may be associated with worsening of disease.

As described previously, adipose tissue produces hormones that regulate blood glucose levels called adipokines. Even as adipose tissue releases adipokines that reducing blood glucose levels, as leptin and adiponectin, adipocytes produce hyperglycemic hormones too, including resistin [106]. The production of resistin is increased in feeding and obesity [107], and its hormone plays a significant role in obesity-induced insulin resistance [108]. The hyperglycemic effect of resistin is associated with decrease of glucose uptake in skeletal muscle cells [109] and severe hepatic insulin resistance [110]. Moreover, reduction in resistin levels by deleting the resistin gene, infusing resistin antibodies or resistin antisense oligodeoxynucleotides protect against obesity-induced hyperglycemia by restoring hepatic insulin responsiveness [108,111,112].

Steppan et al. [113] showed that asthmatic patients present elevated plasma resistin levels and they propose that resistin is associated with increase of asthma severity. However, atopic asthmatics had lower resistin levels compared to non-atopic asthmatic patients and control group, and resistin was negatively associated with eosinophil numbers and serum IgE levels [114]. Hence, the effect of resistin on asthma is unclear yet and need further studies.

\section{PI3K $x$ cAMP on Airway Responsiveness and Inflammation in Asthma}

Hormones that control glucose homeostasis act by distinct signaling pathways. While some hypoglycemic hormones, including insulin and leptin, activate PI3K, the major hyperglycemic hormones, as glucagon and epinephrine, induce increase in the intracellular levels of cAMP $[70,71,115]$. The activation of PI3K plays an important role in the pathogenesis of asthma by stimulating recruitment of mast cells, neutrophils and eosinophils; increasing survival of mast cells and neutrophils; activating mast cells, neutrophils and T cells; inducing proliferation of $\mathrm{T}$ cells and airway smooth muscle cells and differentiation of Th0 cells in Th2 and Th17 cells; promoting airway smooth muscle cell contraction [21,24,116-120] (Figure 2). Moreover, PI3K-knockout mice showed reduction in allergen-induced AHR, airway inflammation and remodeling [121,122], and aerolization of PI3K inhibitor decreased pulmonary eosinophil accumulation and AHR in murine asthma model [123].

Modulation of cAMP levels is a key therapeutic target in asthma, since the increase in cAMP induces relaxation of airway smooth muscle cells. Furthermore, cAMP stimulates apoptosis of mast cells and T cells; inhibits proliferation and activation of $\mathrm{T}$ cells and recruitment and activation of eosinophils [69,124-126] (Figure 2). This difference

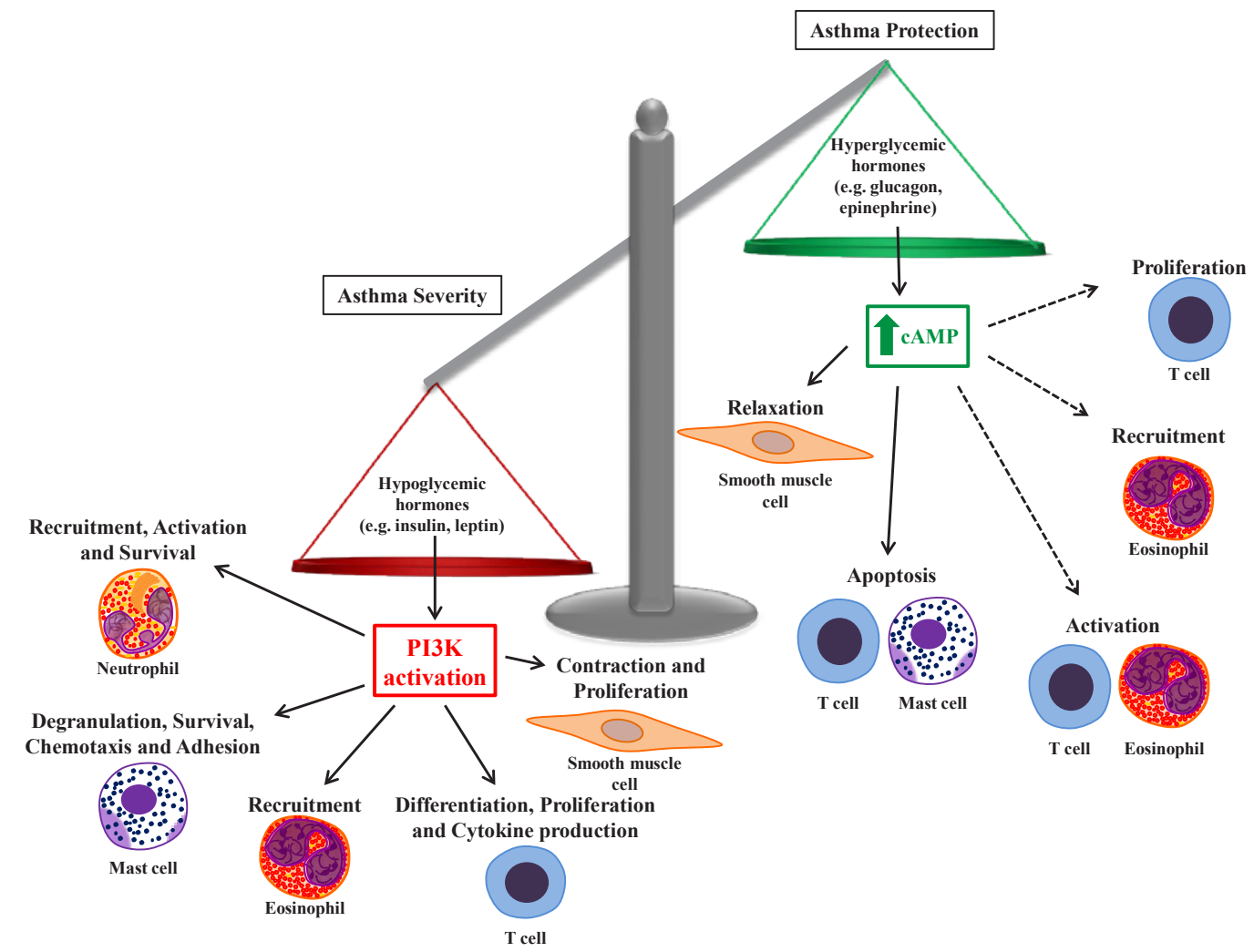

Figure 2: The opposing effects of PI3K and cAMP could explain the divergence between the role of hyperglycemic and hypoglycemic hormones in asthma physiopathology

Glucagon and epinephrine exert their actionsthrough an increase of cAMP intracellular levels. The elevation in cAMP on effectors cells of asthma promotes a range of effects that can reduce airway inflammation and hyperresponsiveness, and therefore improve asthma framework. On the other hand, most of insulin and leptin actions involve PI3K activation thatinduces a pro-inflammatory status in airways of asthmatics, which will aggravate the airway responsiveness. $(\rightarrow)$ : stimulation; $(\rightarrow)$ : inhibition. 
in signaling pathways between hypoglycemic and hyperglycemic hormones could be associated with the opposite effect of these hormones in asthma [127-131].

\section{Conclusion}

The focus of this review has been on hormones that control glucose homeostasis on asthma pathogenesis and development. The fact that some diseases which are characterized by hyperglycemia have an imbalance between hypoglycemic and hyperglycemic hormones and the dichotomy between the effect of these hormones on asthma could explain, at least partly, why diseases like type 1 and type 2 diabetes present opposite incidence of asthma. In addition, a greater knowledge about the role of these hormones in asthma physiopathology may be important for the development of new therapeutic strategies for asthma.

\section{Acknowledgments}

This study was supported by Fundação deAmparo à Pesquisa do Estado do Rio de Janeiro (FAPERJ) Brazil.

\section{References}

1. Hams E, Fallon PG (2012) Innate type 2 cells and asthma. Curr Opin Pharmaco 12: $503-509$

2. Wenzel SE (2012) Asthma phenotypes: the evolution from clinical to molecular approaches. Nat Med 18: 716-725.

3. Lowder TW, Kunz HE (2011) Regulatory T cells in asthma and airway hyperresponsiveness. J Aller Ther S1: 1-8.

4. Hayashi T (2012) Molecular mechanisms of metaplasia, differentiation and hyperplasia of goblet cellin allergic asthma. J Aller Ther 3: 1-10.

5. Bartemes KR, Kita H (2012) Dynamic role of epithelium-derived cytokines in asthma. Clin Immunol 143: 222-235.

6. Chang Y, Al-Alwan L, Risse PA, Halayko AJ, Martin JG, et al. (2012) Th17associated cytokines promote human airway smooth muscle cell proliferation. FASEB J 26: 5152-5160.

7. Poon AH, Eidelman DH, Martin JG, Laprise C, Hamid Q (2012) Pathogenesis of severe asthma. Clin Exp Allergy 42: 625-637.

8. Aronoff SL, Berkowitz K, Shreiner B, Want L (2004) Glucose metabolism and regulation: beyond insulin and glucagon. Diabetes Spectr 17: 183-190.

9. Caffarelli C, Cavagni G, Pierdomenico R, Chiari G, Spattini A, et al. (2004) Coexistence of IgE-mediated allergy and type 1 diabetes in childhood. Int Arch Allergy Immunol 134: 288-294.

10. Karlstad $\varnothing$, Nafstad P, Tverdal A, Skurtveit S, Furu K (2012) Comorbidities in an asthma population 8-29 years old: a study from the Norwegian Prescription Database. Pharmacoepidemiol Drug Saf 21: 1045-1052.

11. Shi HN, Walker WA (2002) T helper cell subclasses and clinical disease states. Curr Opin Gastroenterol 18: 711-716.

12. Rabin RL, Levinson Al (2008) The nexus between atopic disease and autoimmunity: a review of the epidemiological and mechanistic literature. Clin Exp Immunol 153: 19-30.

13. Carvalho VF, Barreto EO, Diaz BL, Serra MF, Azevedo V, et al. (2003) Systemic anaphylaxis is prevented in alloxan-diabetic rats by a mechanism dependent on glucocorticoids. Eur J Pharmacol 472: 221-227.

14. Carvalho VF, Barreto EO, Serra MF, Cordeiro RS, Martins MA, et al. (2006) Aldose reductase inhibitor zopolrestat restores allergic hyporesponsiveness in alloxan-diabetic rats. Eur J Pharmacol 549: 173-178.

15. de F Carvalho V, Campos LV, Farias-Filho FA, Florim LT, Barreto EO, et al. (2008) Suppression of allergic inflammatory response in the skin of alloxandiabetic rats: relationship with reduced local mast cell numbers. Int Arch Allergy Immunol 147: 246-254.

16. Carvalho Vde F, Barreto Ede O, Farias-Filho FA, Gomes LH, Mendonça Lde L, et al. (2009) Reduced expression of IL-3 mediates intestinal mast cell depletion in diabetic rats: role of insulin and glucocorticoid hormones. Int J Exp Patho 90: 148-155.
17. Brealey D, Singer M (2009) Hyperglycemia in critical illness: a review. J Diabetes Sci Technol 3: 1250-1260

18. Saltiel AR, Kahn CR (2001) Insulin signalling and the regulation of glucose and lipid metabolism. Nature 414: 799-806.

19. McMahon GT, Arky RA (2007) Inhaled insulin for diabetes mellitus. N Engl J Med 356: 497-502.

20. Viardot A, Grey ST, Mackay F, Chisholm D (2007) Potential antiinflammatory role of insulin via the preferential polarization of effector $T$ cells toward a $T$ helper 2 phenotype. Endocrinology 148: 346-353.

21. Lessmann E, Grochowy G, Weingarten L, Giesemann T, Aktories K, et al. (2006) Insulin and insulin-like growth factor-1 promote mast cell survival via activation of the phosphatidylinositol-3-kinase pathway. Exp Hematol 34: 1532 1541.

22. Kettner A, Di Matteo M, Santoni A (2010) Insulin potentiates FcepsilonRImediated signaling in mouse bone marrow-derived mast cells. Mol Immuno 47: 1039-1046.

23. Gosens R, Nelemans SA, Hiemstra M, Grootte Bromhaar MM, Meurs H, et al. (2003) Insulin induces a hypercontractile airway smooth muscle phenotype. Eur J Pharmacol 481: 125-131.

24. Dekkers BG, Schaafsma D, Tran T, Zaagsma J, Meurs H (2009) Insulininduced laminin expression promotes a hypercontractile airway smooth muscle phenotype. Am J Respir Cell Mol Biol 41: 494-504

25. Vianna EO, Garcia-Leme J (1995) Allergen-induced airway inflammation in rats. Role of insulin. Am J Respir Crit Care Med 151: 809-814

26. Diaz BL, Serra MF, Alves AC, Pires AL, Corrêa FM, et al. (1996) Alloxan diabetes reduces pleural mast cell numbers and the subsequent eosinophil influx induced by allergen in sensitized rats. Int Arch Allergy Immunol 111: 36 43.

27. Bose M, Teixeira J, Olivan B, Bawa B, Arias S, et al. (2010) Weight loss and incretin responsiveness improve glucose control independently after gastric bypass surgery. J Diabetes 2: 47-55.

28. Hage MP, Safadi B, Salti I, Nasrallah M (2012) Role of Gut-Related Peptides and Other Hormones in the Amelioration of Type 2 Diabetes after Roux-en-Y Gastric Bypass Surgery. ISRN Endocrinol 2012: 504756.

29. Havel PJ, Uriu-Hare JY, Liu T, Stanhope KL, Stern JS, et al. (1998) Marked and rapid decreases of circulating leptin in streptozotocin diabetic rats: reversal by insulin. Am J Physiol 274: R1482-R11491.

30. Cummings BP, Digitale EK, Stanhope KL, Graham JL, Baskin DG, et al. (2008) Development and characterization of a novel rat model of type 2 diabetes mellitus: the UC Davis type 2 diabetes mellitus UCD-T2DM rat. Am J Physio Regul Integr Comp Physiol 295: R1782-R11793.

31. Fujikawa T, Chuang JC, Sakata I, Ramadori G, Coppari R (2010) Leptin therapy improves insulin-deficient type 1 diabetes by CNS-dependent mechanisms in mice. Proc Natl Acad Sci U S A 107: 17391-17396.

32. Park S, Ahn IS, Kim da S (2010) Central infusion of leptin improves insulin resistance and suppresses beta-cell function, but not beta-cell mass, primarily through the sympathetic nervous system in a type 2 diabetic rat model. Life Sc 86: 854-862.

33. Wang MY, Chen L, Clark GO, Lee Y, Stevens RD, et al. (2010) Leptin therapy in insulin-deficient type I diabetes. Proc Natl Acad Sci U S A 107: 4813-4819.

34. Denroche HC, Levi J, Wideman RD, Sequeira RM, Huynh FK, et al. (2011) Leptin therapy reverses hyperglycemia in mice with streptozotocin-induced diabetes, independent of hepatic leptin signaling. Diabetes 60: 1414-1423.

35. Cummings BP, Bettaieb A, Graham JL, Stanhope KL, Dill R, et al. (2011) Subcutaneous administration of leptin normalizes fasting plasma glucose in obese type 2 diabetic UCD-T2DM rats. Proc Natl Acad Sci U S A 108: 1467014675.

36. Morton GJ, Schwartz MW (2011) Leptin and the central nervous system control of glucose metabolism. Physiol Rev 91: 389-411.

37. Tesse R, Schieck M, Kabesch M (2011) Asthma and endocrine disorders: shared mechanisms and genetic pleiotropy. Mol Cell Endocrinol 333: 103-111.

38. Lord GM, Matarese G, Howard JK, Baker RJ, Bloom SR, et al. (1998) Leptin modulates the T-cell immune response and reverses starvation-induced immunosuppression. Nature 394: 897-901. 
39. Wong CK, Cheung PF, Lam CW (2007) Leptin-mediated cytokine release and migration of eosinophils: implications for immunopathophysiology of allergic inflammation. Eur J Immunol 37: 2337-2348.

40. Jartti T, Saarikoski L, Jartti L, Lisinen I, Jula A, et al. (2009) Obesity, adipokines and asthma. Allergy 64: 770-777.

41. Kato H, Ueki S, Kamada R, Kihara J, Yamauchi Y, et al. (2011) Leptin has a priming effect on eotaxin-induced human eosinophil chemotaxis. Int Arch Allergy Immunol 155: 335-344.

42. Shore SA, Schwartzman IN, Mellema MS, Flynt L, Imrich A, et al. (2005) Effect of leptin on allergic airway responses in mice. J Allergy Clin Immunol 115: 103109

43. Giannessi D, Maltinti M, Del Ry S (2007) Adiponectin circulating levels: a new emerging biomarker of cardiovascular risk. Pharmacol Res 56: 459-467.

44. Rabe K, Lehrke M, Parhofer KG, Broedl UC (2008) Adipokines and insulin resistance. Mol Med 14: 741-751.

45. Miller RA, Chu Q, Le Lay J, Scherer PE, Ahima RS, et al. (2011) Adiponectin suppresses gluconeogenic gene expression in mouse hepatocytes independent of LKB1-AMPK signaling. J Clin Invest 121: 2518-2528.

46. Medoff BD, Okamoto Y, Leyton P, Weng M, Sandall BP, et al. (2009) Adiponectin deficiency increases allergic airway inflammation and pulmonary vascular remodeling. Am J Respir Cell Mol Biol 41: 397-406.

47. Shore SA, Terry RD, Flynt L, Xu A, Hug C (2006) Adiponectin attenuates allergen-induced airway inflammation and hyperresponsiveness in mice. $J$ Allergy Clin Immunol 118: 389-395.

48. Ehling A, Schäffler A, Herfarth H, Tarner IH, Anders S, et al. (2006) The potentia of adiponectin in driving arthritis. J Immunol 176: 4468-4478.

49. Kang EH, Lee YJ, Kim TK, Chang CB, Chung JH, et al. (2010) Adiponectin is a potential catabolic mediator in osteoarthritis cartilage. Arthritis Res Ther 12 : R231.

50. Tang CH, Chiu YC, Tan TW, Yang RS, Fu WM (2007) Adiponectin enhances IL-6 production in human synovial fibroblast via an AdipoR1 receptor, AMPK p38, and NF-kappa B pathway. J Immunol 179: 5483-5492.

51. Choi HM, Lee YA, Lee SH, Hong SJ, Hahm DH, et al. (2009) Adiponectin may contribute to synovitis and joint destruction in rheumatoid arthritis by stimulating vascular endothelial growth factor, matrix metalloproteinase-1, and matrix metalloproteinase-13 expression in fibroblast-like synoviocytes more than proinflammatory mediators. Arthritis Res Ther 11: R161.

52. Jung MY, Kim HS, Hong HJ, Youn BS, Kim TS (2012) Adiponectin induces dendritic cell activation via PLCy/JNK/NF-KB pathways, leading to Th1 and Th17 polarization. J Immunol 188: 2592-2601.

53. Holst JJ (2007) The physiology of glucagon-like peptide 1. Physiol Rev 87: 1409-1439.

54. Todd JF, Bloom SR (2007) Incretins and other peptides in the treatment of diabetes. Diabet Med 24: 223-232.

55. Ramnanan CJ, Edgerton DS, Kraft G, Cherrington AD (2011) Physiologic action of glucagon on liver glucose metabolism. Diabetes Obes Metab 13: 118-125

56. Bansal P, Wang Q (2008) Insulin as a physiological modulator of glucagon secretion. Am J Physiol Endocrinol Metab 295: E751-E761.

57. Vuguin PM, Charron MJ (2011) Novel insight into glucagon receptor action: lessons from knockout and transgenic mouse models. Diabetes Obes Metab 13: $144-150$.

58. Dunning BE, Gerich JE (2007) The role of alpha-cell dysregulation in fasting and postprandial hyperglycemia in type 2 diabetes and therapeutic implications. Endocr Rev 28: 253-283

59. Cooperberg BA, Cryer PE (2009) Beta-cell-mediated signaling predominates over direct alpha-cell signaling in the regulation of glucagon secretion in humans. Diabetes Care 32: 2275-2280.

60. Raskin P, Unger RH (1978) Effect of insulin therapy on the profiles of plasma immunoreactive glucagon in juvenile-type and adult-type diabetics. Diabetes 27: 411-419.

61. Reaven GM, Chen YD, Golay A, Swislocki AL, Jaspan JB (1987) Documentation of hyperglucagonemia throughout the day in nonobese and obese patients with noninsulin-dependent diabetes mellitus. J Clin Endocrinol Metab 64: 106-110.
62. Sherman MS, Lazar EJ, Eichacker P (1988) A bronchodilator action of glucagon J Allergy Clin Immunol 81: 908-911.

63. Melanson SW, Bonfante G, Heller MB (1998) Nebulized glucagon in the treatment of bronchospasm in asthmatic patients. Am J Emerg Med 16: 272 275

64. Imbruce R, Goldfedder A, Maguire W, Briscoe W, Nair S (1975) The effect of glucagon on airway resistance. J Clin Pharmacol 15: 680-684.

65. Wilber ST, Wilson JE, Blanda M, Gerson LW, Meerbaum SO, et al. (2000) The bronchodilator effect of intravenous glucagon in asthma exacerbation: a randomized, controlled trial. Ann Emerg Med 36: 427-431.

66. Blumenthal MN, Brody TM (1969) Studies on the mechanism of drug-induced bronchiolar relaxation in the guinea pig. J Allergy 44: 63-69.

67. Authier F, Desbuquois B (2008) Glucagon receptors. Cell Mol Life Sci 65: 18801899.

68. Koh WS, Lee M, Yang KH, Kaminski NE (1996) Expression of functional glucagon receptors on lymphoid cells. Life Sci 58: 741-751.

69. Olsen PC, Coelho LP, da Costa JC, Cordeiro RS, Silva PM, et al. (2012) Two for one: cyclic AMP mediates the anti-inflammatory and anti-spasmodic properties of the non-anesthetic lidocaine analog JMF2-1. Eur J Pharmacol 680: 102-107.

70. Dünser MW, Hasibeder WR (2009) Sympathetic overstimulation during critical illness: adverse effects of adrenergic stress. J Intensive Care Med 24: 293-316.

71. Sharara-Chami RI, Zhou Y, Ebert S, Pacak K, Ozcan U, et al. (2012) Epinephrine deficiency results in intact glucose counter-regulation, severe hepatic steatosis and possible defective autophagy in fasting mice. Int J Biochem Cell Biol 44 905-913.

72. König M, Bulik S, Holzhütter HG (2012) Quantifying the contribution of the liver to glucose homeostasis: a detailed kinetic model of human hepatic glucose metabolism. PLoS Comput Biol 8: e1002577.

73. Fitzgerald PJ (2009) Is elevated noradrenaline an aetiological factor in a number of diseases? Auton Autacoid Pharmacol 29: 143-156.

74. Hu CP, Zou YQ, Feng JT, Li XZ (2012) The effect of unilateral adrenalectomy on transformation of adrenal medullary chromaffin cells in vivo: a potential mechanism of asthma pathogenesis. PLoS One 7: e44586.

75. Rodrigo GJ, Nannini LJ (2006) Comparison between nebulized adrenaline and beta2 agonists for the treatment of acute asthma. A meta-analysis of randomized trials. Am J Emerg Med 24: 217-222.

76. Erdinç $M$ (2011) Beta-2 agonist discussions in asthma and a review of current data. Tuberk Toraks 59: 205-212.

77. Barnes PJ (2011) Biochemical basis of asthma therapy. J Biol Chem 286: 32899-32905.

78. Scola AM, Loxham M, Charlton SJ, Peachell PT (2009) The long-acting betaadrenoceptor agonist, indacaterol, inhibits IgE-dependent responses of human lung mast cells. Br J Pharmacol 158: 267-276.

79. Sartori C, Fang X, McGraw DW, Koch P, Snider ME, et al. (2002) Selected contribution: long-term effects of beta(2)-adrenergic receptor stimulation on alveolar fluid clearance in mice. J Appl Physiol 93: 1875-1880.

80. Yoshida N, Muraguchi M, Kamata M, Ikezono K, Mori T (2009) Procatero potentiates the anti-inflammatory activity of budesonide on eosinophil adhesion to lung fibroblasts. Int Arch Allergy Immunol 150: 352-358.

81. Heijink IH, Vellenga E, Borger P, Postma DS, Monchy JG, et al. (2003) Polarized Th1 and Th2 cells are less responsive to negative feedback by receptors coupled to the AC/cAMP system compared to freshly isolated T cells. Br J Pharmacol 138: 1441-1450.

82. Goleva E, Dunlap A, Leung DY (2004) Differential control of TH1 versus TH2 cell responses by the combination of low-dose steroids with beta2-adrenergic agonists. J Allergy Clin Immunol 114: 183-191.

83. Todorova L, Bjermer L, Westergren-Thorsson G, Miller-Larsson A (2011) TGFßinduced matrix production by bronchial fibroblasts in asthma: budesonide and formoterol effects. Respir Med 105: 1296-1307.

84. Tannheimer SL, Wright CD, Salmon M (2012) Combination of roflumilast with a beta-2 adrenergic receptor agonist inhibits proinflammatory and profibrotic mediator release from human lung fibroblasts. Respir Res 13: 28. 
85. Funder JW (1997) Glucocorticoid and mineralocorticoid receptors: biology and clinical relevance. Annu Rev Med 48: 231-240.

86. Seckl JR (2004) 11beta-hydroxysteroid dehydrogenases: changing glucocorticoid action. Curr Opin Pharmacol 4: 597-602.

87. Giordano R, Guaraldi F, Berardelli R, Karamouzis I, D'Angelo V, et al. (2012) Glucose metabolism in patients with subclinical Cushing's syndrome. Endocrine 41: 415-423

88. Opherk C, Tronche F, Kellendonk C, Kohlmüller D, Schulze A, et al. (2004) Inactivation of the glucocorticoid receptor in hepatocytes leads to fasting hypoglycemia and ameliorates hyperglycemia in streptozotocin-induced diabetes mellitus. Mol Endocrinol 18: 1346-1353

89. Barnes PJ (2006) Corticosteroids: the drugs to beat. Eur J Pharmacol 533 2-14.

90. Chung KF, Caramori G, Adcock IM (2009) Inhaled corticosteroids as combination therapy with beta-adrenergic agonists in airways disease: present and future. Eur J Clin Pharmacol 65: 853-871.

91. Torres RC, Insuela DBR, Carvalho VF (2012) Mecanismos celulares e moleculares da ação antiinflamatória dos glicocorticoides. Corpus et Scientia8: 36-51.

92. Maneechotesuwan K, Yao X, Ito K, Jazrawi E, Usmani OS, et al. (2009) Suppression of GATA-3 nuclear import and phosphorylation: a novel mechanism of corticosteroid action in allergic disease. PLoS Med 6: e1000076.

93. Ziolkowska M, Koc A, Luszczykiewicz G, Ksiezopolska-Pietrzak K, Klimczak E, et al. (2000) High levels of IL-17 in rheumatoid arthritis patients: IL-15 triggers in vitro IL-17 production via cyclosporin A-sensitive mechanism. J Immuno 164: 2832-2838.

94. McKinley L, Alcorn JF, Peterson A, Dupont RB, Kapadia S, et al. (2008) TH17 cells mediate steroid-resistant airway inflammation and airway hyperresponsiveness in mice. J Immunol 181: 4089-4097.

95. Torres RC, Batista MM, Pons AH, Silva AR, Cordeiro RS, et al. (2012) Activation of PPARy by restores mast cell numbers and reactivity in alloxan-diabetic rats by reducing the systemic glucocorticoid levels. Eur J Pharmacol 691: 261-267.

96. Diaz B, Barreto E, Cordeiro R, Perretti M, Martins M, et al. (2001) Enhanced serum glucocorticoid levels mediate the reduction of serosal mast cell numbers in diabetic rats. Life Sci 68: 2925-2932.

97. Dekkers BG, Pehlic A, Mariani R, Bos IS, Meurs H, et al. (2012) Glucocorticosteroids and 32 -adrenoceptor agonists synergize to inhibit airway smooth muscle remodeling. J Pharmacol Exp Ther 342: 780-787.

98. Bos IS, Gosens R, Zuidhof AB, Schaafsma D, Halayko AJ, et al. (2007) Inhibition of allergen-induced airway remodelling by tiotropium and budesonide: a comparison. Eur Respir J 30: 653-661.

99. Ammit AJ, Burgess JK, Hirst SJ, Hughes JM, Kaur M, et al. (2009) The effect of asthma therapeutics on signalling and transcriptional regulation of airway smooth muscle function. Pulm Pharmacol Ther 22: 446-454.

100. Barnes PJ (1998) Efficacy of inhaled corticosteroids in asthma. J Allergy Clin Immunol 102: 531-538.

101. Panettieri RA Jr (2004) Effects of corticosteroids on structural cells in asthma and chronic obstructive pulmonary disease. Proc Am Thorac Soc 1: 231-234.

102. Barnes, PJ (2012) Corticosteroid Therapy for Asthma. Pulmão RJ 21: 53-59.

103. Andersson K, Shebani EB, Makeeva N, Roomans GM, Servetnyk Z (2010) Corticosteroids and montelukast: effects on airway epithelial and human umbilical vein endothelial cells. Lung 188: 209-216.

104. Tomic R, Lassiter CC, Ritzenthaler JD, Rivera HN, Roman J (2005) Anti-tissue remodeling effects of corticosteroids: fluticasone propionate inhibits fibronectin expression in fibroblasts. Chest 127: 257-265

105. Al-Muhsen S, Johnson JR, Hamid Q (2011) Remodeling in asthma. J Allergy Clin Immunol 128: 451-462.

106. Solís Herruzo JA, Pérez Peña F (1973) Erythropoietic protoporphyria (I. Clinical aspects and diagnosis). Rev Clin Esp 128: 451-462.

107. Keenan CR, Salem S, Fietz ER, Gualano RC, Stewart AG (2012) Glucocorticoid-resistant asthma and novel anti-inflammatory drugs. Drug Discov Today 17: 1031-1038.
108. Johnson PR, Burgess JK (2004) Airway smooth muscle and fibroblasts in the pathogenesis of asthma. Curr Allergy Asthma Rep 4: 102-108.

109. Priftis KN, Papadimitriou A, Nicolaidou P, Chrousos GP (2008) The hypothalamic-pituitary-adrenal axis in asthmatic children. Trends Endocrino Metab 19: 32-38.

110. Silverman ES, Breault DT, Vallone J, Subramanian S, Yilmaz AD, et al. (2004) Corticotropin-releasing hormone deficiency increases allergen-induced airway inflammation in a mouse model of asthma. J Allergy Clin Immunol 114: 747754.

111. Rosen ED, Spiegelman BM (2006) Adipocytes as regulators of energy balance and glucose homeostasis. Nature 444: 847-853.

112. Rajala MW, Qi Y, Patel HR, Takahashi N, Banerjee R, et al. (2004) Regulation of resistin expression and circulating levels in obesity, diabetes, and fasting. Diabetes 53: 1671-1679.

113. Steppan CM, Bailey ST, Bhat S, Brown EJ, Banerjee RR, et al. (2001) The hormone resistin links obesity to diabetes. Nature 409: 307-312.

114. Moon B, Kwan JJ, Duddy N, Sweeney G, Begum N (2003) Resistin inhibits glucose uptake in L6 cells independently of changes in insulin signaling and GLUT4 translocation. Am J Physiol Endocrinol Metab 285: E106-E115.

115. Rajala MW, Obici S, Scherer PE, Rossetti L (2003) Adipose-derived resistin and gut-derived resistin-like molecule-beta selectively impair insulin action on glucose production. J Clin Invest 111: 225-230.

116. Banerjee RR, Rangwala SM, Shapiro JS, Rich AS, Rhoades B, et al. (2004) Regulation of fasted blood glucose by resistin. Science 303: 1195-1198.

117. Muse ED, Obici S, Bhanot S, Monia BP, McKay RA, et al. (2004) Role of resistin in diet-induced hepatic insulin resistance. J Clin Invest 114: 232-239.

118. Larochelle J, Freiler J, Dice J, Hagan L (2007) Plasma resistin levels in asthmatics as a marker of disease state. J Asthma 44: 509-513.

119. Kim KW, Shin YH, Lee KE, Kim ES, Sohn MH, et al. (2008) Relationship between adipokines and manifestations of childhood asthma. Pediatr Allergy Immunol 19: 535-540.

120. Frühbeck G (2006) Intracellular signalling pathways activated by leptin Biochem J 393: 7-20.

121. Condliffe AM, Cadwallader KA, Walker TR, Rintoul RC, Cowburn AS, et al (2000) Phosphoinositide 3-kinase: a critical signalling event in pulmonary cells. Respir Res 1: 24-29.

122. Ammit AJ, Panettieri RA Jr (2001) Invited review: the circle of life: cell cycle regulation in airway smooth muscle. J Appl Physiol 91: 1431-1437.

123. Kim MS, Rådinger M, Gilfillan AM (2008) The multiple roles of phosphoinositide 3-kinase in mast cell biology. Trends Immunol 29: 493-501.

124. Ghigo A, Damilano F, Braccini L, Hirsch E (2010) PI3K inhibition in inflammation: Toward tailored therapies for specific diseases. Bioessays 32: 185-196.

125. Jiang H, Xie Y, Abel PW, Toews ML, Townley RG, et al. (2012) Targeting phosphoinositide 3-kinase $y$ in airway smooth muscle cells to suppress interleukin-13-induced mouse airway hyperresponsiveness. J Pharmacol Exp Ther 342: 305-311.

126. Lim DH, Cho JY, Song DJ, Lee SY, Miller M, et al. (2009) PI3K gamma-deficient mice have reduced levels of allergen-induced eosinophilic inflammation and airway remodeling. Am J Physiol Lung Cell Mol Physiol 296: L210-L219.

127. Takeda M, Ito W, Tanabe M, Ueki S, Kato H, et al. (2009) Allergic airway hyperresponsiveness, inflammation, and remodeling do not develop in phosphoinositide 3-kinase gamma-deficient mice. J Allergy Clin Immunol 123 805-812.

128. Doukas J, Eide L, Stebbins K, Racanelli-Layton A, Dellamary L, et al. (2009) Aerosolized phosphoinositide 3-kinase gamma/delta inhibitor TG100-115 [3-[2,4-diamino-6-(3-hydroxyphenyl)pteridin-7-yl]phenol] as a therapeutic candidate for asthma and chronic obstructive pulmonary disease. J Pharmaco Exp Ther 328: 758-765

129. Sarkar A, Sreenivasan Y, Manna SK (2003) alpha-Melanocyte-stimulating hormone induces cell death in mast cells: involvement of NF-kappaB. FEBS Lett 549: 87-93. 
Citation: Insuela DBR, Silva PMR, Martins MA, Carvalho VF (2013) The Yin Yang of Hormones that Control Glucose Homeostasis in Asthma. J Aller Ther S11: 001. doi:10.4172/2155-6121.S11-001

Page 8 of 8

130. Jin SL, Goya S, Nakae S, Wang D, Bruss M, et al. (2010) Phosphodiesterase $4 B$ is essential for $T(H) 2$-cell function and development of airway hyperresponsiveness in allergic asthma. J Allergy Clin Immunol 126: 12521259.
131. Billington CK, Hall IP (2012) Novel cAMP signalling paradigms: therapeutic implications for airway disease. Br J Pharmacol 166: 401-410.

This article was originally published in a special issue, Asthma handled by Editor(s). Dr. Manar Yehia Foda, Department of Endodontics, Cairo University Egypt 